\title{
Articles
}

\section{Is It Time to Reform the Counter-terrorist Financing Reporting Obligations? On the EU and the UK System}

\author{
By Nicholas Ryder*
}

\begin{abstract}
This Article critically considers the effectiveness of the European Union's (EU) counter-terrorist financing (CTF) strategies. In particular, it concentrates on the use of financial intelligence gathered from the submission of suspicious activity reports (SARs) by reporting entities to Member States Financial Intelligence Units (FIU). The Article identifies a series of weaknesses in the United Kingdom's (UK) reporting regime: Defensive reporting, increased compliance costs, and the definition of suspicion. It concludes by making a series of recommendations that are aimed at improving the effectiveness of the EU and UK CTF reporting obligations.
\end{abstract}

\footnotetext{
* Dr. Ryder is a Professor in Financial Crime at Bristol Law School and Faculty of Business and Law at the University of the West of England, Bristol.
} 


\section{A. Introduction}

The European Union is suffering from the second decade of the most intense wave of international terrorism since the 1970s. Within this recent wave, nation states have been increasingly subjected to terrorist attacks. For example, since 2016 there have been terrorist attacks in France, Belgium, Germany, Sweden, Spain, Turkey, the United Kingdom, Finland, and Russia. These terrorist attacks have three common themes: Evidence of a sophisticated terrorist support network, the use of low capability weapons, and inexpensive acts of terrorism. This Article focuses on the last of these three themes.

The al-Qaeda terrorist attacks in September 2001 resulted in the introduction of a wealth of legislative and innovative enforcement provisions designed to tackle terrorism and its financing. These measures were heavily influenced by the declaration of the War on Terrorism by President George Bush and the UN's introduction of several Security Council Resolutions that sought to tackle international acts of terrorism. The terrorist attacks acted as a galvanizing factor for both the international community and the many nation states who had previously neglected to tackle the threat posed by terrorist financing. Therefore, for the purpose of this Article, the most significant part of the War on Terror is the Financial War on Terrorism.

This Article is divided into three parts. The first section concentrates on the anti-money laundering (AML) legislative measures of the United Nations (UN), the EU, and the soft law Recommendations of the Financial Action Task Force (FATF). The section highlights how the AML reporting obligations focused on the proceeds of drug trafficking offences and not terrorism. This approach has been categorized as a profit-driven reporting model directed at targeting the proceeds of financial crime. The second section moves on to highlight the influence that the terrorist attacks on September 11, 2001, (9/11) had on extending the profit-reporting model to the financing of terrorism. This second section illustrates that the profit reporting model is inappropriate when applied to the financing of terrorism. Accordingly, the section is further divided into two sub-parts. The first sub-part illustrates that terrorists may exploit an extensive array of financial mechanisms to circumvent CTF reporting mechanisms. The second sub-part notes the increasing threat posed by inexpensive acts of terrorism to further highlight the weaknesses of the CTF reporting obligations. Here, specific reference is made to several inexpensive terrorist attacks that have taken place within the EU. The third section of the Article focuses on the United Kingdom (UK) and critically assesses the effectiveness of its CTF reporting obligations.

I. The US Financial War on Terror 
President George Bush initiated the Financial War on Terrorism on September 24, 2001, ${ }^{1}$ with his solemn declaration: "We will starve terrorists of funding, turn them against each other, rout them out of their safe hiding places, and bring them to justice." ${ }^{2}$ The Financial War on Terrorism resulted in a seismic alteration in the financial crime strategies of an international community that had previously concentrated on money laundering. This approach, as outlined below, was wholly inadequate for dealing with how the 9/11 terrorists were financed. The National Commission on the Terrorist Attacks Upon the United States noted that "the 19 operatives were funded by al-Qaeda, either through wire transfers or cash provided by [Khalid Sheikh Mohammed] . . .." ${ }^{3}$ The National Commission added that some of the terrorists received wire transfers ranging between $\$ 5,000$ to $\$ 70,000^{4}$ and added that Khalid Sheikh Mohammed had "delivered a large amount of cash, perhaps $\$ 120,000$, to the plot facilitator Abdul Aziz Ali in Dubai . . . ." Abdul Aziz Ali sent several bank-to-bank transfers -including transactions for $\$ 10,000, \$ 20,000$, and $\$ 70,000$ - to bank accounts at the SunTrust Bank in Florida belonging to two of the terrorists: Marwan al Shehhi and Muhamad Atta. ${ }^{6}$ The amount of each of these transactions is important because US deposit taking institutions are legally required to complete and submit a Currency Transaction Report (CTR) to the Financial Crime Enforcement Network (FinCEN) for all financial transactions of $\$ 10,000$ or more. The Financial Recordkeeping and Reporting of Currency and Foreign Transactions Act, or Bank Secrecy Act of 1970 imposes this obligation. ${ }^{7}$ SunTrust Bank was thus required to submit the CTRs to FinCEN and file a SAR for any wire transfer that they deemed to be suspicious. ${ }^{8}$ Nevertheless, the National Commission found that "no financial institution [had] filed a Suspicious Activity Report (SAR) in connection with any transaction of any of the 19 hijackers before 9/11" and that "[e]ven in hindsight, there [was] nothing . . . to indicate that any SAR should have been filed or [that] the hijackers

\footnotetext{
${ }^{1}$ See Press Release, President George Bush, President Freezes Terrorists' Assets (Sep. 24, 2001) (on file with author).

${ }^{2}$ Press Release, Office of the Press Secretary, Fact Sheet on Terrorist Financing Executive Order (Sep. 24, 2001), (on file with author). It is not the purpose of this Article to provide a detailed commentary on the Financial War on Terrorism. For a more detailed examination on the subject please see NICHOLAS RYDER, THE FINANCIAL WAR ON TERROR: A ReView of Counter-Terrorist FinANCING Strategies SinCE 2001 30-62 (2015).

${ }^{3}$ NAT'l COMmission on TerRorist AtTACKS Upon the U.S., The 9/11 Commission Report 172 (2004) [hereinafter The NATIONAL COMMISSION].

${ }^{4}$ John Roth, DOUglas GREenburg \& SERENA WiLle, NAT'L COMMISSION ON TERRORIST ATtACKS UPON THE U.S, MONOGRAPH ON TERRORIST FINANACING 53 (2004) [hereinafter THE MONOGRAPH].

${ }^{5}$ Id. at 26.

${ }^{6}$ THE MONOGRAPH, supra note 4 , at 132.

731 U.S.C. $§ 5311$ (2012).

${ }^{8}$ The Annunzio-Wylie Anti-Money Laundering Act of 1992, § 1517(b), Pub. L. No. 102-550, 106 Stat. 3762 (1992) (introducing the obligation to submit a suspicious activity report).
} 
[should have] otherwise [been] reported to law enforcement.." ${ }^{9}$ This conclusion is perhaps best explained by the inherent inadequacy of the Bank Secrecy Act of 1970 in curtailing terrorist financing. The Bank Secrecy Act of 1970 was not meant to tackle the problem terrorist financing and was instead introduced to "build a system to combat organized crime and white-collar crime and to deter and prevent the use of secret foreign bank accounts for tax fraud." ${ }^{10}$

Prior to the terrorist attacks, terrorist financing had attracted limited attention in a number of academic studies. For example, researchers in the US had concentrated their efforts on assessing the prevention of other types of financial crimes, including money laundering ${ }^{11}$ and fraud. ${ }^{12}$ The evolution of the US literature on money laundering can be traced and presented in chronological order through the enactment of legislation: the Bank Secrecy Act of $1970,{ }^{13}$ the Racketeer Influence and Corrupt Organization Act of $1970,{ }^{14}$ the Money Laundering Control Act of 1986, ${ }^{15}$ the Annunzio-Wylie Anti-Money Laundering Act of 1992, ${ }^{16}$ and the USA Patriot Act of $2001 .{ }^{17} \mathrm{~A}$ similar picture can be presented of the approach adopted by researchers of financial crime policies and legislative provisions of the EU. A plethora of research has been published on the EUs AML Directives,${ }^{18}$ the EU's counter-fraud

\footnotetext{
${ }^{9}$ THE MONOGRAPH, supra note 4, at 141.

${ }^{10}$ Hearings Before the Subcomm. on Fin. Inst. of the Comm. on Banking and Currency, 91st Cong. 170 (1970) (statement of Eugene Rossides, Former Assistant Secretary, Treasury for Enforcement and Operations).

${ }^{11}$ See generally Mike Levi \& Peter Reuter, Money Laundering, 34 CRIME \& JUST. 289 (2006).

${ }^{12}$ See generally Ellen Podgor, Criminal Fraud, 48 AM. U. L. Rev. 729 (1999).

${ }^{13}$ See generally Sarah Hughes, Policing Money Laundering through Funds Transfers: A Critique of Regulation under the Bank Secrecy Act, 67 IND. L.J. 283 (1992).

${ }^{14}$ See generally Barry Tarlow, RICO Revisited, 17 GA. L. REV. 291 (1983).

${ }^{15}$ See generally Joshua Schwartz, Liability for Structured Transactions under the Currency and Foreign Transactions Reporting Act: A Prelude to the Money Laundering Control Act of 1986, 6 ANN. REV. BANKING L. 315 (1987).

${ }^{16}$ See generally Matthew Hall, Note, An Emerging Duty to Report Criminal Conduct: Banks, Money Laundering, and the Suspicious Activity Report, 84 Ky. L. J. 643 (1995-1996).

${ }^{17}$ See generally Andres Rueda, International Money Laundering Law Enforcement and the USA Patriot Act of 2001, 10 Mich. St. U. Det. C. OF L. J. Of INT'L L. 141 (2001).

${ }^{18}$ See generally Valsamis Mitsilegas \& Bill Gilmore, The EU Legislative Framework Against Money Laundering and Terrorist Finance: A Critical Analysis in Light of Evolving Global Standards, 56 INT'L \& COMP. L.Q. 119 (2007).
} 
measures under the management of the European Anti-Fraud Office, ${ }^{19}$ market manipulation, ${ }^{20}$ insider dealing, ${ }^{21}$ and market abuse. ${ }^{22}$

The terrorist attacks in September 2001 resulted in the publication of numerous interesting studies on the threat posed by the financing of terrorism. For example, commentators began to take an interest in the funding models used by al-Qaeda, ${ }^{23}$ the association between misapplied charitable donations and terrorists, ${ }^{24}$ the interpretation of the Financial War on Terrorism, and the efforts by the international community to tackle terrorist financing. ${ }^{25}$ More recently, scholars have concentrated on the funding streams of Islamic State of Iraq and the Levant. ${ }^{26}$ While the association between the EU and the financing of terrorism has attracted some academic commentary, a large proportion of it has concentrated on other types of financial crimes and only a small number of studies have reviewed the EUs stance on terrorist financing. ${ }^{27}$ Normark and Ranstrop noted that none of the published research on terrorist financing in the EU has presented a "high-resolution picture of the sources of funding for terrorist plots." 28 Therefore, this Article seeks to provide an enhanced understanding of the weaknesses of the EU's CTF reporting obligations, the continued threat posed by inexpensive acts of terrorism, and the extensive array of sources that fund acts of terrorism.

\section{B. International Financial Crime Legislative Measures: The Profit Model}

\footnotetext{
${ }^{19}$ See generally Xavier Groussot \& Ziva Popov, What's Wrong with Olaf-Accountability, Due Process and Criminal Justice in European Anti-Fraud Policy, 47 Common MKT. L. ReV. 605 (2010).

${ }^{20}$ See generally R.C.H. ALEXANDER, INSIDER DeALING AND MONEY LAUNDERING IN THE EU: LAW AND RegULATION (2007).

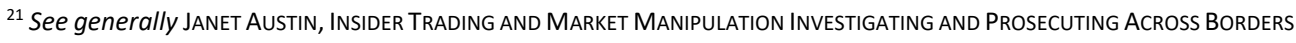
(2017).

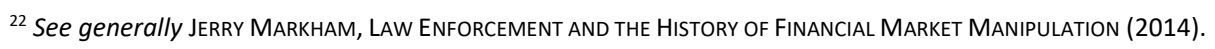

${ }^{23}$ See generally Rohan Gunaratna, Inside Al QAeda: Global Network of Terror (2002).

${ }^{24}$ See generally Jimmy Gurule, Unfunding Terror: The Legal ReSPonse to the Financing of Global Terrorism (2008).

${ }^{25}$ See generally RYDER, supra note 2 .

${ }^{26}$ See generally RYDER, supra note 2 .

${ }^{27}$ See The National Commission, supra note 3.

${ }^{28}$ Magnus Normark \& Magnus Ranstrop, Understanding Terrorist Finance- Modus Operandi and National CTF REGIMES 8 (2015).
} 


\section{The Profit Model}

Before $9 / 11$, international efforts against financial crime focused on tackling the laundering of the proceeds from the illegal manufacturing, distribution, and sale of narcotic substances. These measures largely originate from the US led War on Drugs, a term commonly associated with a series of controversial legislative measures introduced by President Richard Nixon in the 1970s. ${ }^{29}$ The UN adopted these legislative measures in the form of the Convention Against Illicit Traffic in Narcotic Drugs and Psychotropic Substances of 1988 (the Vienna Convention of 1988). This was followed by the UN Convention Against Transnational Organized Crime of 2000 (the Palermo Convention of 2000) and extended by the UN Convention Against Corruption of 2003. ${ }^{30}$ Similarly, the EU introduced the Money Laundering Directives of 1993 and 2001 to tackle the laundering of narcotic substances. ${ }^{31}$ The FATF published its first set of money laundering Recommendations in $1990 .{ }^{32}$ Collectively, these measures were described as a "major breakthrough in attacking the benefits derived from drug trafficking activities and ... a forceful endorsement of the notion that attacking the profit motive is essential if the struggle against drug trafficking is to be effective." ${ }^{33}$ Nelen stated that "by dismantling their organi[z]ations financially, criminals must be hit at their supposedly more vulnerable spot: [T]heir assets." ${ }^{34}$ Nevertheless, the profit driven model is not appropriate when used against the financing of terrorism. The financial process adopted by terrorists to accumulate funds is different from the processes adopted by money launderers. Terrorist financing is more commonly referred to as reverse money laundering, where clean or legitimate money is transformed into dirty money that is then funneled to finance acts of terrorism. Comparatively, regular money laundering involves the conversion of dirty or illegal money into clean money via its laundering through three recognized phases: Placement, layering, and integration. Therefore, the extension of the profit model to tackle the financing of terrorism is inappropriate.

\footnotetext{
${ }^{29}$ See generally Dan Baum, SMOKe ANd Mirrors: The WAR on Drugs AND the Poltics of Fallure (1997).

30 See Nicholas Ryder, Money Laundering-An Endless Cycle? A Comparative Analysis of the Anti-Money Laundering Policies IN THE United States of AMericA, the United KIngdom, Australia ANd CANAdA 8-39 (2012) (providing a more detailed discussion of international anti-money laundering legislative provisions).

${ }^{31}$ See Directive 91/308, of the European Council on the Prevention of the Use of the Financial System to Launder Money, 1993 O.J. (L 166); Directive 2001/97/EC, of the European Parliament and of the Council of 4 December 2001 Amending Council Directive 91/308/EEC on Prevention of the Use of the Financial System for the Purpose of Money Laundering, 2001 O.J. (L 344).

32 See Financial action TASk Force, The 40 Recommendations (2004).

${ }^{33}$ D.W. Sproule \& Paul St-Denis, The UN Drug Trafficking Convention: An Ambitious Step, 27 CANADIAN Y.B. OF INT‘L L. 263, 281-82 (1990).

${ }^{34}$ Hans Nelen, Hit Them Where it Hurts Most? The Proceeds-of-Crime Approach in the Netherlands, 41 CRIME, L. \& SOC. CHANGE 517 (2004).
} 
Nonetheless, the profit driven model contains a number of preventative measures that require the reporting entities of signatory states to implement a series of pre-placement money laundering reporting obligations. For example, Article 7 of the Palermo Convention of 2000 provides that each signatory should implement a far-reaching AML regime for a wide range of reporting entities that are vulnerable to money laundering. The scheme should include requirements for customer identification, record keeping, and the reporting of suspicious transactions. ${ }^{35}$ Furthermore, it provides that signatories shall "consider the establishment of a financial intelligence unit to serve as a national center for the collection, analysis and dissemination of information regarding potential money laundering." ${ }^{36}$ Additionally, the FATF Recommendations outline a number of preventative measures aimed at tackling the threat posed by money laundering. ${ }^{37}$ For example, Recommendations 10 and 11 relate to customer due diligence and record keeping obligations. ${ }^{38}$ Recommendations 12 to 16 provide additional measures for specific customers and activities, which include politically exposed persons, correspondent banking, money or transfer value services, new technology, and wire transfers. ${ }^{39}$ Recommendations 17 to 19 deal with reliance, control, and financial groups, while Recommendations 20 and 21 deal with the reporting of suspicious transactions and the criminal offense of "tipping off." 40

The EU profit-reporting model began in the 1970s when the European Council's European Committee on Crime Problems created a Select Committee to investigate the illegal transfer of proceeds from crime between member states. The Select Committee made a recommendation stipulating that banks should ensure that identity checks are undertaken on all clients when an account is opened or money deposited. ${ }^{41}$ This recommendation, however, was not fully implemented. Another set of AML measures were proposed when the European Ministers of Justice asked the European Committee on Crime Problems to create a stance regarding the proceeds of drug trafficking that paralleled the one adopted

\footnotetext{
${ }^{35}$ G.A. Res. 55/25, United Nations Convention Against Transnational Organized Crime art. 7(1)(a) (Jan. 8, 2001)..

${ }^{36} / d$. art. $7(1)(b)$ (extending these measures through Article 14 of the United Nations Convention Against Corruption).

${ }^{37}$ FINANCIAL ACtION TASK FORCE, THE FATF RECOMMENDATIONS: INTERNATIONAL STANDARDS ON COMBATING MONEY LAUNDERING AND THE FINANCING OF TERRORISM \& PROLIFERATION 12-17 (2012).

${ }^{38}$ Id. at 14-15.

${ }^{39}$ Id. at 16-17.

${ }^{40} / d$. at $18-19$.

${ }^{41}$ Kern Alexander, Multi-National Efforts to Combat Financial Crime and the Financial Action Task Force, 2 J. OF INT'L FIN. MKTS. 182 (2000).
} 
by the UN. ${ }^{42}$ It was not until the introduction of the First Money Laundering Directive that there was a coordinated effort to impose the profit model on Member States. ${ }^{43}$ The Directive contained several important features based upon 40 recommendations from the FATF which included the need to ensure client identification, the examination and reporting of suspicious transactions, indemnities for good faith reporting of suspicious transactions, storage of identification records extending for five years beyond the end of the client relationship, co-operation with the authorities, and the adoption of adequate internal procedures and training programs. Nevertheless, the First Money Laundering Directive concentrated on combating the laundering of drug proceeds though the financial sector instead of combating the financing of terrorism. At the start of the new millennia, it became clear that the scope of the First Directive was too narrow. ${ }^{44}$ Accordingly, the EU introduced a broader Second Money Laundering Directive that expanded the list of predicate offences for which the suspicious transaction reports were compulsory. This new list ranged from drug trafficking offences to all serious criminal offences.

\section{The Influence of $9 / 11$}

In 1994, the UN adopted the term "terrorist financing" through its Declaration to Eliminate International Terrorism. ${ }^{45}$ Subsequently, a General Assembly Resolution called for Member States to "take steps to prevent and counteract, through appropriate domestic measures, the financing of terrorists and terrorist organizations." ${ }^{46}$ Nevertheless, the scope of this Resolution was limited to terrorist bombings and nuclear terrorism. The al-Qaeda bombings of the US embassies in Kenya and Tanzania resulted in a re-think causing the passing of Resolutions $\mathrm{A} / \mathrm{RES} / 52 / 165$ and $\mathrm{A} / \mathrm{RES} / 53 / 108$, which in turn highlighted the need to tackle the financing of terrorism. ${ }^{47}$ Consequently, the International Convention for the Suppression of the Financing of Terrorism of 1999 criminalized the collection or distribution of funds for the purposes of supporting an act of terrorism. ${ }^{48}$ Despite the importance of preventing terrorist financing, only 41 UN Member States signed the Convention, with only 6 ratifying

\footnotetext{
${ }^{42}$ Id.

${ }^{43}$ See Directive 91/308, of the European Council on the Prevention of the Use of the Financial System to Launder Money, 1993 O.J. (L 166).

${ }^{44}$ See Mitsilegas, supra note 18.

${ }^{45}$ G.A. Res. 49/60, Annex (Dec. 9, 1994).

${ }^{46}$ G.A. Res. 51/210 (Dec. 17, 1996); see also G.A. Res. 45/121, Eighth United Nations Congress on the Prevention of Crime and the Treatment of Offenders (Dec. 14, 1990).

${ }^{47}$ G.A. Res. 52/165, para. 3 (Dec. 15, 1997); G.A. Res. 53/108, para. 11 (Jan. 26, 1999).

${ }^{48}$ International Convention for the Suppression of the Financing of Terrorism, arts. 2(1)(a)(b), 4, Dec. 9, 1999, 2178 U.N.T.S. 197.
} 
it. ${ }^{49}$ Additionally, it is also important to consider UN Security Council Resolution 1267, which created a sanctions regime that targeted individuals and entities associated with al-Qaeda, Osama bin Laden, and/or the Taliban. Another important measure was UN Security Council Resolution 1269, which asked nation states to implement the UN's anti-terrorist conventions. More specifically, the Resolution provided that countries should, inter alia:

[P]revent and suppress in their territories through all lawful means the preparation and financing of any acts of terrorism; deny those who plan, finance or commit terrorist acts safe havens by ensuring their apprehension and prosecution or extradition; take appropriate measures in conformity with the relevant provisions of national and international law, including international standards of human rights, before granting refugee status, for the purpose of ensuring that the asylum-seeker has not participated in terrorist acts; [and] exchange information in accordance with international and domestic law, and cooperate on administrative and judicial matters in order to prevent the commission of terrorist acts .... ${ }^{50}$

The terrorist attacks of 9/11 led to a monumental shift in attitudes towards the detection and prevention of terrorist financing. The International Convention served as a precedent for UN Security Council Resolution 1373. This Resolution imposes four obligations on members of the UN: ${ }^{51}$ (i) it specifically requires states to thwart and control the financing of terrorism; (ii) it criminalizes the collection of terrorist funds in states territory; (iii) it freezes funds, financial assets, and economic resources of people who commit or try to commit acts of terrorism; and (iv) it prevents any nationals within their territories from providing funds, financial assets, and economic resources to people who seek to commit acts of terrorism. ${ }^{52}$ This UN Security Council Resolution is the most important international legislative measure that seeks to prevent terrorist financing. ${ }^{53}$ In contrast to the 1999 Convention, all 191 Member States submitted reports to the UN Security Council Counter-Terrorism Committee on the actions they had taken to suppress international terrorism, which included how they

\footnotetext{
${ }^{49}$ See Angela Leong, Chasing Dirty Money: Domestic and International Measures Against Money Laundering, $10 \mathrm{~J}$. MONEY LAUNDERING CONTROL 145 (2007).

${ }^{50}$ S.C. Res. 1269 , para. 4 (Oct. 19, 1999).

${ }^{51}$ See Cabinet Office, The UK and the Campaign Against International Terrorism-Progress Report 24 (2002).

52 S.C. Res. 1373, para. 1 (Sept. 28, 2001).

${ }^{53}$ See Anders Kruse, Financial and Economic Sanctions-From a Perspective of International Law and Human Rights, 12 J. FIN. CRIME 218 (2005).
} 
have gone about blocking terrorist finances as required by Resolution $1373 .{ }^{54}$ Nevertheless, in 2004, the European Commission concluded that it was necessary to introduce a Third Money Laundering Directive ${ }^{55}$ to extend the scope of its reporting obligations to include the financing of terrorism. ${ }^{56}$ The Third Directive came into force in December 2005 and Member States were required to implement it by December 2007. In June 2017, a Fourth Money Laundering Directive repealed the Third Directive following the publication of a new set of FATF Recommendations in 2012. ${ }^{57}$ The Fourth Directive introduced several important amendments that included an alteration in the risk-based approach, new rules to deal with the threat posed by electronic money, registers for ultimate beneficial owners, and an improved sanctions regime. What becomes clear after briefly highlighting the response to the terrorist attacks in September 2001 is that the UN, FATF, and EU have continued to mistakenly use the profit-driven reporting model to tackle the financing of terrorism. The Article has thus far illustrated how the Bank Secrecy Act of 1970 was unsuitable to prevent the $9 / 11$ terrorists from acquiring the necessary finances via several wire transfers. The next Section of the Article provides more evidence demonstrating that the profit reporting model is inappropriate for tackling the financing of terrorism.

\section{Sources of Terrorist Financing and Inexpensive Terrorism}

The first part of this Section provides a commentary on the extensive number of sources that terrorists may exploit to fund their activities. Each of these sources has been designed to avoid having to interact with reporting entities. The second part of this Section concentrates on the increasing number of terrorist attacks that can be classified as inexpensive acts of terrorism.

\section{Sources of Terrorist Financing}

Preventing terrorist financing is difficult because of the large number of mechanisms that may be used to fund acts of terrorism. ${ }^{58}$ Traditionally, terrorists have relied on two sources

\footnotetext{
${ }^{54}$ The White house, Progress Report on the Global War on Terrorism 6 (2003).

55 Directive 2005/60/EC, of the European Parliament and of the Council of 26 October 2005 on the Prevention of the Use of the Financial System for the Purpose of Money Laundering and Terrorist Financing, 2005 O.J. (L 309) (repealed).

${ }^{56}$ Richard Alexander, Reputational Issues Arising Under the EU Third Money Laundering Directive, 27 COMPANY LAW. 373 (2006).

${ }^{57}$ Directive 2015/849, of the European Parliament and of the Council of 20 May 2015 on the Prevention of the Use of the Financial System for the Purposes of Money Laundering or Terrorist Financing, 2015 O.J. (L 141) (EU).

${ }^{58}$ See Matthew Levitt, Stemming the Flow of Terrorist Financing: Practical and Conceptual Challenges, 27 FLETCHER F. WORLD AFF. 63, 64 (2003).
} 
of funding: State and private sponsors. ${ }^{59}$ State sponsored terrorism refers to nation states providing logistical and financial support to terrorist organizations. ${ }^{60}$ Since the terrorist attacks in 2001, state-sponsored acts of terrorism have declined and the trend has shifted to terrorists receiving funding from private sponsors or donors. ${ }^{61}$ As acknowledged by the official report on the terrorist attacks on London on July 7, 2005, terrorist organizations have also become increasingly self-sufficient. ${ }^{62}$ Terrorists generate funds through a broad spectrum of measures including kidnappings, robberies, and drug trading. ${ }^{63}$ Other sources include counterfeiting ${ }^{64}$ and the sale of conflict diamonds. ${ }^{65}$ Terrorists have also acquired funding through traditional criminal activities, including benefit and credit card fraud, identity theft, the sale of counterfeit goods, and drug trafficking. ${ }^{66}$ The wide range of sources available to terrorists is illustrated by the activities of ISIL, who have exploited four funding streams: The control of oil reserves, kidnappings, foreign and private financial benefactors, and antiquities. Another terrorist group that utilizes a vast array of sources is Al Shabaab, a Somali-based militant Islamist group that has obtained funding from the illegal smuggling of ivory. ${ }^{67} \mathrm{Al}$ Shabaab have "earned more than $\$ 25$ million a year from illicit exports of charcoal to Gulf Arab states and from taxing the trucking of charcoal to the Somali ports of Kismayu and Barawe." 68 The UN reported that Al Shabaab receives a majority of its funding via charcoal exports and the illegal importation of contraband sugar. ${ }^{69}$

\footnotetext{
${ }^{59}$ Ilias Bantekas, The International Law of Terrorist Financing, 97 AM. J. OF INT'L L. 315 (2003).

${ }^{60}$ Alison Chase, Legal Mechanisms of the International Community and the United States Concerning State Sponsorship of Terrorism, 45 VA. J. INT'L L. 41 (2004).

${ }^{61}$ See Mark Basile, Going to the Source: Why Al Qaeda's Financial Network is Likely to Withstand the Current War on Terrorist Financing, 27 STUD. IN CONFLICT \& TERRORISM 183 (2004).

62 House of Commons, Report of The OfFicial ACCOUnt of the Bombings in LONDON ON 7TH JULy 200523 (2005).

${ }^{63}$ Peter Alldridge, Money Laundering LaW 215 (2003).

${ }^{64}$ Peter Lowe, Counterfeiting: Links to Organised Crime and Terrorist Funding, 13 J. FIN. CRIME 255 (2006).

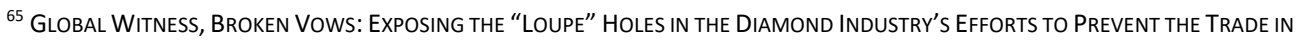
CONFLICT DIAMONDS (2003).

${ }^{66}$ Courtney Linn, How Terrorists Exploit Gaps in US Anti-Money Laundering Laws to Secrete Plunder, 8 J. MONEY LAUNDERING CONTROL 200 (2005).

${ }^{67}$ VIdhi Doshi, Elephant Campaign: How Africa's 'White Gold' Funds the al-Shabaab Militants, THE INDEPENDENT NEWSPAPER (Feb. 3, 2014), http://www.independent.co.uk/voices/campaigns/elephant-campaign/elephantcampaign-how-africas-white-gold-funds-the-alshabaab-militants-9102862.html.
}

68 William Maclean, Shabaab Finances Face Squeeze After Kenya Attack, ReUTERS (Sep. 26, 2013), http://www.reuters.com/article/2013/09/26/us-kenya-attack-shabaab-funding-idUSBRE98P05Z20130926.

${ }^{69}$ See Rep. of the Monitoring Group on Somalia and Eritrea Pursuant to Security Council Resolution 2060 (2012): Somalia, U.N. Doc. S/2013/413 (2013). 
Another example of a terrorist group that has been able to exploit a wide range of sources of funding are Boko Haram. Boko Haram are funded "through black market dealings, local and international benefactors, and links to al-Qa[e]da and other well-funded groups in the Middle East." 70 The Inter-governmental Action Group against Money Laundering in West Africa noted that Boko Haram has been partly financed through private donors and misapplied charitable donations. ${ }^{71}$ The FATF provided several examples of how Boko Haram acquires its financing including the sale of goods and other lucrative activities, business profits/logistical support, extortion of civilians through intimidation, proceeds from arms smugglers and cash couriers, and financial contributions of political leaders. ${ }^{72}$ The prevention and detection of terrorist financing is impossible. Such difficulties are partly due to the ability of terrorists to exploit an extensive array of financial resources that necessarily lie outside of the scope of reporting mechanisms. The extension of the profit-driven reporting model is unsuitable for the financing of terrorism because it is aimed at preventing legitimate entities from accepting deposits of proceeds from criminal activities. Terrorists are unlikely to deposit funds in a heavily regulated sector that is subject to reporting obligations.

\section{Cheap Terrorism}

In addition to the wide array of funding avenues available to terrorists, it is also important to discuss the concept of inexpensive terrorism. The threat posed by inexpensive terrorism was identified by Her Majesty's Treasury who took the view that the "UK experience bears out the relatively low costs required for an effective terrorist attack. The Bishopsgate bomb in the City of London in 1993 caused over f1bn worth of damage to property yet cost only $£ 3,000$ to mount." 73 Another example of inexpensive terrorism was the first attack on the World Trade Center in 1993, where six people were murdered and over 1,000 were injured at an estimated cost of only $\$ 400$. This terrorist attack was "less devastating ... because of the group's limited financial resources." ${ }^{74}$ Two years after the World Trade Center attack, Timothy McVeigh detonated a truck bomb outside of the Alfred P. Murrah Federal Building in Oklahoma City. In an interview with MSNBC, Timothy McVeigh estimated that the total costs of the attack, including the truck rental, fertilizer, nitro methane, and other costs

\footnotetext{
${ }^{70}$ Terrence McCoy, Paying for Terrorism: Where Does Boko Haram Gets its Money From? THE INDEPENDENT NEWSPAPER (June 6, 2014), http://www.independent.co.uk/news/world/africa/paying-for-terrorism-where-does-boko-haramgets-its-money-from-9503948.html.

71 Inter Governmental Action Group Against Money Laundering in West Africa, Threat Assessment of Money LAUNDERING AND TERRORIST FINANCING IN WEST AFRICA 94 (2010).

72 FINANCIAL ACTION TASK FORCE, supra note 37.

73 Ed Moloney, A SeCret History OF THE IRA (2002) 291.

${ }^{74}$ Thomas Biersteker \& Sue Eckert, Introduction in COUNTERING THE FINANCING OF TERRORISM 1 (Thomas Biersteker and Sue Eckert eds., 2008).
} 
amounted to $\$ 5,000 .^{75}$ The terrorist attacks by Al Shabaab on the Westgate Mall in Kenya "cost less than $\$ 5,000$ to execute, and the materials used in the Boston Marathon bombings [in 2013] reportedly cost about $\$ 500 . " 76$ The two explosive devices used by the bombers, Tamerlan and Dzhokhar Tsarnaev, cost as little as $\$ 100$ each. ${ }^{77}$ In none of these terrorist attacks was there any evidence of a SAR submitted to a FIU by a reporting entity. Furthermore, the terrorist attacks in London on July 7, 2005, cost were estimated to have cost between $£ 100$ and $£ 200 .{ }^{78}$ Waszak estimated that "the cost of making a suicide bomb can be as low as $\$ 5$, while the deployment of a suicide bomber including transportation and reconnaissance, can cost as little as $\$ 200$." 79 Therefore, if the terrorist or terrorist cell is significantly self-sufficient, there is no need for them to be involved in funding activities that would lead to the submission of an SAR by a reporting entity.

More recently, there has been an increase in the number of inexpensive acts of terrorism within Members States of the EU. For example, in August 2017, a terrorist driving a van killed 13 people in Barcelona. In June 2017, one person was killed outside Finsbury Park Mosque in a terrorist attack, while terrorists killed eight others on London Bridge and Borough Market. A month before the terrorist attacks in London, 23 people were killed and 59 others were injured following a terrorist attack by a suicide bomber in Manchester. Additional terrorist attacks within the EU occurred in Paris, Stockholm, Berlin, Normandy, Nice, and Brussels. Several of these attacks have involved terrorists using a rental vehicle to target pedestrians. Of course, the relative ease of self-funding the renting of a vehicle provides further evidence that demonstrates how inexpensive forms of terrorism exploit loopholes in the profit reporting model. There are two common themes in these type of terrorist attacks: The use of low capability weapons and the relative inexpensiveness associated with such acts of terrorism. These two factors illustrate that extending the profit reporting model to tackle the financing of terrorism is unsuitable for achieving the intended goal.

\section{The United Kingdom}

75 "The McVeigh Tapes: Confessions of An American Terrorist," NBC News (Apr. 15, 2010), http://www.nbcnews.com/id/36135258/ns/msnbc_tv/\#.VDJpOU10zIU.

${ }^{76}$ Remarks of Under Secretary for Terrorism and Financial Intelligence David Cohen Before the Center for a New American Security on "Confronting New Threats in Terrorist Financing," U.S. DEP'T OF TREASURY (March 4, 2014), https://www.treasury.gov/press-center/press-releases/Pages/jl2308.aspx.

77 Todd Wallack \& Beth Healy, Tsarnaev Brothers Appeared to Have Scant Finances, Boston GLOBE (Apr. 24, 2013), http://www.bostonglobe.com/metro/2013/04/23/tsarnaev-brothers-appeared-have-scantfinances/ZbNBuN2Gcz8IOFddKDIUON/story.html.

${ }^{78}$ See Jeffrey Robinson, Brown's War Just Doesn't Add Up: You Can't Kill Terrorist With a Calculator, THE TIMES NEWSPAPER (Feb. 14, 2006), http://www.thetimes.co.uk/tto/law/columnists/article2049933.ece.

79 John Waszak, The Obstacles to Suppressing Radical Islamic Terrorist Financing, 36 CASE WESTERN RES. J. INT‘L L. 673 (2004). 
The UK has a long history of tackling terrorism and has accordingly introduced extensive legislation dealing with the subject of preventing the financing of terrorism. The development of the UK's terrorist related legislation is associated with the end of the eighteenth century and the start of the nineteenth century. Such legislative measures included the Explosive Substances Act of 1883, Criminal Law and Procedure (Ireland) Act of 1887, and the Civil Authorities (Special Powers) Act (Northern Ireland) of $1922 .{ }^{80}$ One of the first terrorist financing related legislation was the Prevention of Terrorism (Temporary Provisions) Act of 1989 which criminalized terrorist financing, ${ }^{81}$ attempted controls of terrorist financing, ${ }^{82}$ and imposed forfeiture provisions on items used to support acts of terrorism..$^{83}$ The next legislative amendment was the Criminal Justice Act of 1993, which brought terrorist financing provisions that were in line with the antimoney laundering measures in the Drug Trafficking Offences Act of 1986. Additionally, the Criminal Justice (Terrorism and Conspiracy) Act of 1998 permitted the courts to order into forfeiture any property connected with proscribed terrorist organizations. ${ }^{84}$ The Terrorism Act of 2000 also created a number of criminal offences relating to the financing of terrorism. ${ }^{85}$ These were further extended by the Anti-terrorism, Crime, and Security Act of 2001; the Terrorism Act of 2006; the Counter-Terrorism Act of 2008; the Terrorist Asset-Freezing etc. Act of 2010; the Crime and Courts Act of 2013; the Serious Crime Act of 2015; the Money Laundering, Terrorist Financing, and Transfer of Funds Regulations of 2017; and the Criminal Finances Act of 2017.

\section{CTF Reporting Obligations}

A key part of the UK's CTF measures has been the reporting requirements on financial institutions where there is a risk of money laundering or terrorist financing. The first money laundering reporting requirements were contained in the Drug Trafficking Offences Act of 1986. The Criminal Justice Act of 1993 amended these reporting obligations after the introduction of the First Money Laundering Directive. The Proceeds of Crime Act of 2002 and the Money Laundering Regulations of 2017 have since consolidated these reporting

\footnotetext{
${ }^{80}$ Ben Brandon, Terrorism, Human Rights and the Rule of Law: 120 years of the UK's Legal Response to Terrorism, CRIM. L. REV. 981, 982 (2004).

${ }^{81}$ Prevention of Terrorism (Temporary Provisions) Act 1989 c. 4, § 9 (Eng.) (repealed).

${ }^{82} / d . \S \S 9,11$.

$83 / d . \S 13$.

${ }^{84}$ Criminal Justice (Terrorism and Conspiracy) Act 1998 c. 40, § 4(3) (Eng.) (repealed).

${ }^{85}$ Terrorism Act 2000 c. 11, §§ 15-9 (Eng.).
} 
obligations. ${ }^{86}$ The Terrorism Act makes it a criminal offense to fail to disclose knowledge or suspicion of another person that has committed an offense under the terrorist financing criminal offences. ${ }^{87}$ Such a failure to disclose information is identical to the offense of failing to disclose information under the Proceeds of Crime Act 2002. ${ }^{88}$ An individual or organization who suspects that an offense has been committed under the Terrorism Act 2000 is legally required to complete a SAR. In addition to the traditional means of gathering financial intelligence via the use of SARs the Terrorism Act 2000 also contained a number of statutory measures related to financial information orders. For example, Schedule 6 of the Terrorism Act 2000 "deals with orders empowering the police to require financial institutions to supply customer information relevant to terrorist investigation." ${ }^{89}$ An application for an order can be made by a police officer that could "require a financial institution [to which the order applies] to provide customer information for the purposes of the investigation." 90 The order could apply to "(a) all financial institutions, (b) a particular description, or particular descriptions, of financial institutions, or (c) a particular financial institution or particular financial institutions." 91 If a financial institution fails to comply with the financial information order it is guilty of a criminal offence. ${ }^{92}$ The financial institution, however, does have a defense to breaching the financial information order when they can illustrate that "(a) that the information required was not in the institution's possession, or (b) that it was not reasonably practicable for the institution to comply with the requirement.." ${ }^{\prime 3}$ Additionally, the Terrorism Act 2000 permits the use of account monitoring orders. ${ }^{94}$ Leong stated that an account monitoring order

[I]s an order that the financial institution specified in the application for the order must, for the period stated in the order, provide account information of the description specified in the order to an appropriate

\footnotetext{
${ }^{86}$ The Money Laundering, Terrorist Financing and Transfer of Funds (Information on the Payer) Regulations 2017, SI 2017/692 (Eng.).

${ }^{87}$ Terrorism Act 2000, s.19.

${ }^{88}$ Proceeds of Crime Act 2002, c. 4, §§ 330-32 (Eng).

${ }^{89}$ Omer Elagab, Control of Terrorist Funds and the Banking System, 21 J. OF INT'L BANKING L. \& REG. 40 (2006).

${ }^{90}$ Terrorism Act 2000 c. 11, sch. 6 (Eng.).

${ }^{91} / d$.

${ }^{92} / d$.

${ }^{93} / d$.

${ }^{94} / d$.
} 
officer in the manner, and at or by the time or times, stated in the order. ${ }^{95}$

Judges can grant an account monitoring order if they are satisfied that "(a) the order is sought for the purposes of a terrorist investigation, (b) the tracing of terrorist property is desirable for the purposes of the investigation, and (c) the order will enhance the effectiveness of the investigation." 96 When an application is made for account monitoring, the order must contain information relating to accounts of the person who is subject to the order. ${ }^{97}$

One of the most controversial pieces of CTF legislation is the Counter-Terrorism Act 2008. The Act "has added to those financial provisions in significant ways. The Act implements a new regime of financial directions in Schedule $7 \ldots$ the scheme is very wide-ranging in application and effect." 98 Goldby stated that the Counter-Terrorism Act "provides new antimoney laundering and counter-terrorism financing provisions applicable to the private sector." 99 Schedule 7 of the 2008 Act provides Her Majesty's Treasury with the ability to give a direction where the FATF has requested actions to be pursued against a country in which risks of terrorist financing or money laundering are present. Furthermore, Her Majesty's Treasury is permitted to impose an action where it reasonably believes that a country poses a significant risk of terrorist financing or money laundering to the UK. Finally, Her Majesty's Treasury may impose a direction where it believes there is substantial risk to the UK posed by the development, manufacturing, or facilitation of the development of nuclear, radiological, biological, or chemical weapons. The second part of Schedule 7 outlines the class of people that may become subject to the direction, which includes people working in the financial sector. Schedule 7 of the Counter-Terrorism Act 2008 further provides the sort of obligations that can be imposed. For example, obligations can be imposed on transactions or business relationships where a person carries on business activities in the country or with the government of the country, or where the person is a resident of or incorporated in the country in which the business activities occur. Once a direction has been imposed pursuant to Schedule 7 of the Counter-Terrorism Act 2008, the recipient will be required to improve their due diligence measures. Part 5 of Schedule 7 permits the relevant enforcement agency to obtain information and part 6 permits the use of financial sanctions on those who fail to

\footnotetext{
${ }^{95}$ Angela Leong, Financial Investigation: A Key Element in the Fight Against Organised Crime, 27 Company LaW. 219 (2006).

${ }^{96}$ Terrorism Act 2000 c.11, sch. 6(5) (Eng.).

${ }^{97}$ ld.

${ }^{98}$ Gareth Rees \& Tim Moloney, The Latest Efforts to Interrupt Terrorist Supply Lines: Schedule 7 to the CounterTerrorism Act 2008, CRIM. L. REV. 127 (2010).

${ }^{99}$ Myriam Goldby, The Impact of Schedule 7 of the Counter-Terrorism Act 2008 on Banks and Their Customers, $13 \mathrm{~J}$. of MONEY LAUNDERING CONTROL 352 (2010).
} 
observe the directions. The powers of Her Majesty's Treasury under Schedule 7 of the Counter-Terrorism Act 2008 were challenged in Bank Mellat v. HM Treasury (No.2). ${ }^{100}$ Here, the Supreme Court determined that the directions authorized by Her Majesty's Treasury under Schedule 7 breached Article 6 of the European Convention of Human Rights as well as the rules of natural justice.

There are a number of other weaknesses that are associated with the reporting of suspicious transactions and the financing of terrorism. For example, one of the most common criticisms lies in the seemingly unsatisfactory approach that courts have taken with regard to the definition of the term "suspicion." ${ }^{101}$ Courts have offered sparse guidance on the term as it relates to the money laundering reporting obligations imposed by the Proceeds of Crime Act 2002. For example, in the case of $R v$. Da Silva, the court stated that "the essential element of the word suspect and its affiliates, in this context, is that the defendant must think that there is a possibility, which is more than fanciful, that the relevant facts exist. A vague feeling of unease would not suffice." ${ }^{102}$ Further guidance on the interpretation of suspicious activity is offered by the Joint Money Laundering Steering Group who stated that:

Suspicion has been defined by the courts as being beyond mere speculation and based on some foundation, for example: "[a] degree of satisfaction and not necessarily amounting to belief but at least extending beyond speculation as to whether an event has occurred or not ... [and] [a]lthough the creation of suspicion requires a lesser factual basis than the creation of a belief, it must nonetheless be built upon some foundation." 103

The reporting obligations have contributed to a sense of fear among the regulated sector that has caused a dramatic increase in the number of SARs submitted to FIUs. For example, between 1995 and 2002, the number of SARs submitted to the UK's FIU increased from 5,000 to 60,000 . More recently, it has been reported that the UK FIU received 210,524 SARs in

\footnotetext{
${ }^{100}$ Bank Mellat v. HM Treasury [2013] UKSC 39 (Eng.).

${ }^{101}$ Terrorism Act 2000 c.11, § 19 (Eng.).

${ }^{102}$ R v. Da Silva [2006] EWCA (Crim) 1654 (Eng.); see also K v. Nat'I Westminster Bank [2006] EWCA (Civ) 1039 (Eng.); Shah v. HSBC [2010] 3 All ER (EC) 477 (Eng.).

103 Joint Money Laundering Steering Group, PreVention of Money Laundering/Combating Terrorist Financing 2011 REVIEW VERSION 133 (2011).
} 
$2008,{ }^{104} 240,582$ in $2010,{ }^{105} 247,601$ in $2011,{ }^{106} 278,665$ in $2012,{ }^{107} 316,527$ in $2013,{ }^{108}$ 354,186 in 2014, 381,882 in 2015, and 643,000 in 2017. ${ }^{109}$ There are a number of possible reasons for these increases. First, the increase may be directly attributable to the threat of sanctions by organizations like the Financial Conduct Authority, which has imposed a tactic upon the regulated sector that has been referred to as defensive or preventative' reporting. Second, reporting entities have complained about the significant increase in compliance costs, which has resulted in suggestions that the CTF reporting requirements could be abandoned and that resources should be redirected elsewhere

\section{BREXIT}

On June 24, 2016, the electorate determined that it no longer wanted the UK to be a member of EU. Will this decision have any impact on how the UK complies with the EU AML and CTF obligations? The UK is at the forefront of the international and regional efforts to tackle financial crime. The UK has implemented a number of international money laundering legislative instruments. For example, it signed the Vienna Convention in December 1988 that was then ratified in June 1991. ${ }^{110}$ The impact of the Vienna Convention is illustrated by the Criminal Justice (International Co-operation) Act (1990), part two of which is also entitled the Vienna Convention. Furthermore, the judiciary has taken the Vienna Convention into account on several occasions in relevant money laundering cases. Such cases include $R v$. Montila, ${ }^{111} R$ v. Rezvi, ${ }^{112}$ Crown Prosecution Service v. Richards, ${ }^{113}$ Lodhi v. Governor of Brixton Prison (No.2), ${ }^{114}$ and $R$ v. Hussain. ${ }^{115}$ The UK signed the UN Convention against Transnational Organized Crime, or Palermo Convention in December 2000, and ratified it in

\footnotetext{
${ }^{104}$ Serious Organised Crime Agency, The Suspicious Activity Reports Regime AnNuAl Report 200815 (2008).

105 Serious Organised Crime Agency, The Suspicious Activity Reports Regime AnNual Report 20104 (2011).

${ }^{106}$ Serious Organised Crime Agency, The Suspicious Activity Reports Regime AnNual Report 2011 (2012).

107 Serious Organised Crime Agency, The Suspicious Activity Reports Regime AnNual Report 2012 (2013).

${ }^{108}$ NAT'L CRIME Agency, The Suspicious Activity RePorts Regime ANNUAL RePORT 20135 (2014).

${ }^{109}$ See National Crime Agency, The Suspicious Activity Reports Regime Annual Report 2017 (2018)

${ }^{110}$ Financial Action TASk Force, Third Mutual Evaluation Report Anti-Money Laundering and Combating the Financing OF TERrorism: THE UNITED KINGdOM OF GREAT BRITAIN AND NORTHERN IRELAND 250 (2007).

${ }^{111}$ R v. Montila [2005] 1 All ER 113 (Eng.).

${ }^{112}$ R v. Rezvi [2002] 1 All ER 801 (Eng.).

${ }^{113}$ Crown Prosecution Service v. Richards [2006] EWCA (Civ) 849 (Eng.).

${ }^{114}$ Lodhi v Governor of Brixton Prison [2002] EWHC (Admin) 2029 (Eng.).

${ }^{115}$ R v. Hussain [2002] EWCA (Crim) 6 (Eng.).
} 
February 2006. Evidence of its influence is illustrated by its being referenced in the Serious Organized Crime and Police Act (2005). ${ }^{116}$ Furthermore, the UK has fully implemented the UN Convention against Corruption 2003 via the enactment of the Bribery Act 2010.

The UK is also obliged to implement several money AML legislative provisions from the EU. For example, the EU introduced the Council of Europe Convention on Laundering, Search, Seizure and Confiscation of the Proceeds from Crime (1990). ${ }^{117}$ The UK signed the Convention in November 1990 and it was ratified in September 1992. The scope of this Convention was broadened by the Council of Europe through the Convention on Laundering, Search, Seizure, and Confiscation of the Proceeds from Crime and on the Financing of Terrorism (2005), which was adopted in Warsaw in 2005 and entered into force in 2008. In addition, the EU has introduced four Money Laundering Directives, which have all been implemented by the UK in 1993, ${ }^{118} 2003,{ }^{119} 2007,{ }^{120}$ and by the Money Laundering, Terrorist Financing and Transfer of Funds (Information on the Payer) Regulations 2017. ${ }^{121}$ The UK has also fully implemented UN Security Council Resolutions 1267 and $1373 .{ }^{122}$ The latter of these Security Council Resolutions was introduced by the Terrorism (United Nations Measures) Order 2001,123 Terrorism (United Nations Measures) Order 2006, ${ }^{124}$ and the Terrorism (United Nations Measures) Order 2009. ${ }^{125}$ Her Majesty's Treasury manages the financial sanctions regime by virtue of the Terrorist Asset-Freezing etc. Act 2010, which is also assisted by the directions given under Schedule 7 to the Counter Terrorism Act 2008 as well as Council Regulation (EU) No.833/2014. The UK proactively implemented legislative measures to keep consistency between the practices of the UN and EU, and it seems highly unlikely that the UK will fail to guarantee its commitment to implementing the financial crime provisions.

\footnotetext{
${ }^{116}$ Serious Organised Crime and Police Act 2005 c.4, § 95 (Eng.).

${ }^{117}$ Convention on Laundering, Search, Seizure, and Confiscation of the Proceeds from Crime and on the Financing of Terrorism, Aug. 11, 1990, ETS No 141. 


\section{Conclusions and Recommendations}

This Article was written during an unprecedented era of inexpensively financed acts of terrorism in the EU and its Member States. France has experienced a large number of inexpensive terrorist incidents that include the attacks on Charlie Hebdo and the Hyper Cacher which resulted in the death of 17 people. In November 2015, eight terrorists instigated several concurrent acts of terrorism murdering 130 people and injuring 350 at a concert, an international football match, and at surrounding restaurants. Additionally, there were several terrorist attacks in Turkey associated with ISIL and the PKK. ${ }^{126}$ UK citizens have been subjected to terrorist attacks in Sousse in 2015, the attempted murder of two train commuters in December 2015, and the terrorist attacks outlined in the second Section of this Article. Therefore, it is essential that the CTF reporting obligations become an effective mechanism for preventing terrorists from being able to move and access their funds. EUROPOL, however, concluded that " 2016 has seen lower amounts of funds moved regularly through the financial sector. These small denomination values sent by [terrorist] supporters and family members are transferred to support [terrorists] and their organi[z]ational expenses." ${ }^{127}$

The Article thus provided a critical examination of the appropriateness and effectiveness of the use of the profit reporting model in the fight to suppress the financing of terrorism. The Article illustrated how the UN, FATF, and the EU have all introduced reporting mechanisms that aim to prevent money laundering in a wide range of institutions that receive deposits. The differences between money laundering and terrorist financing are clear and the profit model is inappropriate for tackling the financing of terrorism. Therefore, a new approach needs to be considered by the international community and the UK. The second part of the Article provides extensive evidence that illustrates that the CTF reporting obligations have done very little to prevent acts of terrorism from being financed. The wide variety of sources that terrorists use suggests that they obtain or transfer financing from resources that inherently lie outside the remit of the CTF reporting obligations. Detecting and preventing terrorist finances under the CTF reporting regime is thus extremely difficult if not impossible-especially considering the extensive financial tools available and the low costs of terrorist operations. The final part of the Article provides a commentary on the UKs efforts to implement the CTF reporting obligations. The UK has fully implemented the international AML and CTF reporting obligations that are outlined in the first part of the Article. Further, it is likely that Brexit will have a minimal effect on these obligations. Nevertheless, the UK has mistakenly adopted the profit or reporting model to fight the financing of terrorism. The Article accordingly highlights several weaknesses in this latter approach, including the inappropriate definition of suspicious, the increased costs of compliance, and a fear within

\footnotetext{
${ }^{126}$ UNited StATES DEPARTMENT OF STATE, COUNTRY REPORTS ON TERRORISM 88-89 (2016).

${ }^{127}$ EUROPOL, EUROPEAN UNION TERRORISM SITUATION AND TREND REPORT 201712 (2017).
} 
reporting entities that has resulted in defensive reporting. To tackle the threat posed by terrorist financing, this Article suggests that reporting entities, FIUs, policy makers, and the international community adopt a different and innovative approach. Such an approach would involve revisiting the interpretation of suspicious and departing from a definition aimed at money launderers that attempt to disguise large sums of illegally obtained funds. Importantly, deposit taking institutions should focus their CTF obligations not on suspicious deposits that they receive, but on suspicious withdrawals. Such examples could include bank accounts that are closed with little or no notice, irregular cash withdrawals that are inconsistent with the financial character or behavior of the account holder, or an unexpected use of an overdraft. The scope of CTF reporting obligations must reach beyond institutions that receive deposits and should include providers of credit, especially considering the use of student loans to finance acts of terrorism in Manchester and Brussels. Extending reporting obligations to providers of credit could limit one funding avenue that has been previously exploited by terrorists. The success of such an approach would doubtlessly require a closer working relationship between the reporting entities themselves and the FIU. 